\title{
6 Geneva, Reykjavik, Washington, and Moscow,
}

\section{$1985-1988$}

\author{
Jonathan Hunt and David Reynolds
}

\section{[place Figure 6.1 here]}

The sight of the leaders of the United States and the Soviet Union strolling amicably together past St. Basil's Cathedral captivated onlookers in Red Square on 31 May 1988 (see Figure 6.1). Even more striking was what the two leaders actually said. Five years earlier, President Ronald Reagan had likened the USSR to an 'evil empire', which exported communist revolution even as it crushed dissent within the Soviet bloc. Yet on that spring day in 1988 he sang a new tune. When asked by one American reporter whether he still believed that his hosts were 'the evil empire', he recanted: 'I was talking about another time, another era.' Standing beside him, the Soviet leader Mikhail Gorbachev felt vindicated; via backchannels in March he had urged Reagan to make precisely such a statement. The President's words signalled an acknowledgement that a new Soviet Union was emerging thanks to Gorbachev's reforms. The Soviet leader uttered a single word in reply: 'Right.'

\footnotetext{
${ }^{1}$ Michael R. Beschloss and Strobe Talbott, At the Highest Levels: The Inside Story of the End of the Cold War (London, 1993), 9; Memcon, President and Suzanne Massie, 11 March 1988, National Security Archive, George Washington University, Washington, DC, electronic briefing book (henceforth NSAEBB), no. 251, doc no. 4, http://nsarchive.gwu.edu/NSAEBB/NSAEBB251/4.pdf. Mikhail Gorbachev, Memoirs (New York, 1996), 590.
} 
That moment in Red Square was the high water mark of a remarkable odyssey for each leader. Reagan had entered the Oval Office in January 1981 as a tough-talking anticommunist. He left eight years later having presided over a revolution in world affairs as East-West relations evolved from the resurgent antagonism of the 'New Cold War' after the Soviets' 1979 invasion of Afghanistan to peaceful engagement by the end of his second term in January 1989. In Moscow, Gorbachev became General Secretary of the Communist Party of the Soviet Union (CPSU) in March 1985 as a cautious domestic reformer. When his political career ended in December 1991, the Cold War was over. So were his party and his country.

Gorbachev's domestic reforms required a major revision of Soviet foreign policy in order to end an arms race whose costs were bankrupting vital sectors of the national economy. Reagan seized on Soviet anxieties, not only for narrow American advantage, but also because of his utopian vision of a nuclear-free world. Capitalizing on a rare moment of convergence in international politics, often in defiance of their more hawkish advisers, the two leaders transformed superpower relations through face-to-face diplomacy in a remarkable series of four summits between 1985 and 1988. ${ }^{2}$ Their parleys in Geneva, Reykjavik, Washington and Moscow started by establishing personal trust and culminated

\footnotetext{
${ }^{2}$ General overviews include Raymond L. Garthoff, The Great Transition: American-Soviet Relations and the End of the Cold War (Washington, DC, 1994); Jack F. Matlock, Jr., Reagan and Gorbachev: How the Cold War Ended (New York, 2004); James Graham Wilson, The Triumph of Improvisation: Gorbachev's Adaptability, Reagan's Engagement, and the End of the Cold War (Ithaca, NY, 2014); and on summitry, David Reynolds, Summits: Six Meetings that Shaped the Twentieth Century (New York, 2007), ch. 7.
} 
in a treaty abolishing intermediate-range nuclear forces (INF) - the first time that the United States and the Soviet Union had agreed to eliminate an entire category of nuclear weapons. Even though the backlash against the treaty among the military in both capitals retarded progress on a superpower strategic arms reduction treaty (START), the INF treaty signed in Washington in 1987 significantly defused tensions in the European theatre at a crucial juncture in the Cold War. The contribution of summitry to these achievements is the theme of this chapter.

\section{SHUFFLING TOWARDS A SUMMIT}

In the 1980 presidential campaign, Reagan contrasted his assertiveness about America's might and right against Jimmy Carter's alleged feebleness in response to the Iranian hostage crisis and the Soviet invasion of Afghanistan. But Reagan's attitude to diplomacy was more nuanced once in office. ${ }^{3}$ This was set out clearly in National Security Decision Directive (NSDD) 75 in January 1983, which delineated three guiding principles for US policy towards the USSR: first, 'to contain and over time reverse Soviet expansionism;' second, to promote 'the process of change in the Soviet Union'; and third, 'to engage the

\footnotetext{
${ }^{3}$ Simon Miles, “Quiet Diplomacy:' The Reagan Administration's Initial Engagement with the Soviet Union', unpublished paper presented at the annual meeting of the Society for Historians of American Foreign Relations, Lexington, Kentucky, 21 June 2014; James Mann, The Rebellion of Ronald Reagan: A History of the End of the Cold War (New York, 2009).
} 
Soviet Union in negotiations to attempt to reach agreements' ${ }^{4}$ Reagan's long-standing antipathy toward communism and his brusque dismissal of Nixon and Kissinger's policies of détente inspired fierce rhetorical claims, such as his declaration that 'the march of freedom and democracy' would 'leave Marxism-Leninism on the ash-heap of history, as it has left other tyrannies'5 His conviction that 'military strength is a prerequisite to peace' was used to justify the massively increased defence budgets of his early years. Nonetheless, Reagan wanted to encourage any signs of greater pluralism in the Soviet system: hence his support for dissidents demanding human rights or religious freedom. The President believed that a combination of geopolitical muscle and diplomatic flexibility might persuade the Soviets to renounce their 'religious bent for global hegemony.' He warned that stark ultimatums would 'make it impossible for them to give in'; his preference was instead to 'sit around a table and tell the Russians quietly' ${ }^{6}$. Even though any summit was clearly a long way off, his private letters to Soviet leaders were intended to establish some kind of personal rapport. ${ }^{7}$ George Shultz, secretary of state from 1982 to 1989, supported the

\footnotetext{
${ }^{4}$ 'National Security Decision Directive (NSDD) 75: US relations with the USSR, 17 January 1983', in Jason Saltoun-Ebin, ed., The Reagan Files: Inside the National Security Council (Santa Barbara, CA, 2nd edn, 2014), 217.

${ }^{5}$ David E. Hoffman, The Dead Hand: The Untold Story of the Cold War Arms Race and its Dangerous Legacy (New York, 2009), 44.

6 'Minutes, NSC Meeting, Sanctions, 18 June 1982', in Saltoun-Ebin, The Reagan Files, 185.

7 'Letter, Ronald Reagan to Liuba Vaschenko, 11 October 1984', in Kiron Skinner, Annelise Anderson, and Martin Anderson, eds, Reagan: A Life in Letters (New York, 2003), 380.
} 
president, believing that a two-pronged strategy of fortifying national strength while conducting limited and firm dialogue could yield 'a more stable', if still 'competitive', Soviet-American relationship. ${ }^{8}$

Reagan's intellectual complexities were most evident in his approach to nuclear weapons. It is ironic that the president who advocated 'peace through strength' and authorized one of the biggest arms build-ups of the Cold War did not, at heart, believe in the nuclear option. He was convinced that the Pentagon's deterrence doctrine of Mutual Assured Destruction (MAD) was literally mad because the human cost of a major U.S.Soviet nuclear war would be annihilation. Many of Reagan's advisers believed that he could never have brought himself to authorise the use of nuclear weapons. Since his days in Hollywood, Reagan held what has been described as a 'visionary, even utopian' belief in nuclear abolitionism. His gut instinct was confirmed by a visit in the summer of 1979 to the North American Aerospace Defense Command (NORAD) in Colorado Springs - nerve centre for tracking a potential nuclear attack - which was carved into the Rocky Mountains and encased in steel and concrete. In response to Reagan's questioning, however, the commanding general admitted that one Soviet SS-18 missile 'would blow us away' and that the best NORAD could do for any American city was to give its people ten to fifteen minutes notice of their extermination. Reagan was appalled. 'We have spent all that money

\footnotetext{
${ }^{8}$ Ronald Reagan Presidential Library, Simi Valley CA (henceforth RRPL), Robert McFarlane files, Reorganized Archival Collection (henceforth RAC) box 3, Memorandum, Shultz to Reagan: USG-Soviet relations, 3 March 1983.
} 
and have all that equipment', he told an aide, 'and there is nothing we can do to prevent a nuclear missile from hitting us'. ${ }^{9}$

Yet Reagan also felt that the nuclear arms race would serve as an ideological litmus test, proving the superiority of capitalism over communism in providing both guns and butter. He accordingly pursued contradictory aims as president, hoping to eliminate nuclear weapons entirely, while using massive military spending to apply pressure on the Soviets. His ends were peaceful but the means he used were often confrontational. And he failed to rein in the internecine feuding amongst his advisers - Reagan had no less than six National Security Advisers during his eight years in office - which added to the confused and discordant messages emanating from Washington.

The practice of 'quiet diplomacy' was therefore a minor theme of Reagan's first term. In 1983 superpower relations remained fundamentally adversarial, with tensions fuelled by ongoing Soviet human rights violations and geo-ideological competition in Central America. The president's public statements added fuel to the fire. On 8 March he branded the Soviet Union an 'evil empire' at an evangelical conference in Florida. Two weeks later, on 23 March, he unveiled his Strategic Defense Initiative (SDI) - a programme to build a shield of space-based defences and neutralize ballistic missiles with the intent of eventually rendering nuclear weapons 'impotent and obsolete'. But what Reagan offered as the prelude to a nuclear-free world was seen by the Soviets as a new and alarming high-tech twist to the arms spiral. This was also the view of many critics in the West, who dubbed the

\footnotetext{
${ }^{9}$ Paul Lettow, Ronald Reagan and his Quest to Abolish Nuclear Weapons (New York, 2005), xi, 37-8.
} 
initiative 'Star Wars'. The President's rhetoric infuriated Moscow. Veteran Foreign Minister Andrei Gromyko denounced his 'organized crusade' against the Soviet Union and said any tally of evil in the two systems would show that 'the height of the curve for the U.S.A. would be hundreds of times higher than ours'. ${ }^{10}$

Superpower relations sunk to a new low that autumn. In September Soviet MiGs mistakenly shot down a South Korean civilian passenger jet that had strayed into Soviet airspace, killing 270 people. Reagan damned the attack as a 'crime against humanity . . an act of barbarism, born of a society which wantonly disregards individual rights and the value of human life and seeks constantly to expand and dominate other nations'. In November Moscow over-reacted to a NATO exercise 'Able Archer'. The KGB alerted the Kremlin that this might be the build-up to a Western surprise attack on the USSR. CIA Deputy Director Robert Gates later admitted a general failure in Washington 'to grasp the true extent of [Soviet] anxiety. ${ }^{11}$

Diplomacy had also broken down over arms control. SALT II remained unratified and the second track of NATO's 1979 Brussels decision (namely negotiations over INF) had completely stalled. To be sure, in November 1981 Reagan had proposed a zero-zero

\footnotetext{
${ }^{10}$ John F. Burns, ‘Gromyko rejects Reagan arms plan', New York Times, 3 April 1983, 10.

${ }^{11}$ Reagan, Address to the Nation on the Soviet Attack on a Korean Civilian Airliner, 5 September 1983, The American Presidency Project (henceforth APP) website, http://www.presidency.ucsb.edu/ws/index.php?pid=41788\&st=007\&st1. Robert M. Gates, From the
} Shadows: The Ultimate Insider's Story of Five Presidents and How They Won the Cold War (New York, 1996), 273. 
solution to the INF conundrum, offering to cancel NATO's future Cruise and Pershing deployments if the Soviets would dismantle their existing SS-20s and other INFs. On Reagan's part this was a genuine expression of his anti-nuclear creed but the Pentagon saw it as a public relations gesture. And the Kremlin - as the American hawks always expected - naturally rejected the 'zero option' as one-sided. After the Soviets walked out of arms control talks in 1983 the Americans went ahead with the implementation of track one, to strengthen and modernize NATO's INFs by deploying cruise and Pershing II missiles in Germany, Italy and the United Kingdom. These new NATO deployments were implemented in 1984, despite intense public opposition from peace groups and the European left. Not only had arms control proved ineffectual; the nuclear confrontation in Europe seemed to be escalating to new and more dangerous levels.

The Soviet reaction to Able Archer shocked Reagan, and prompted one of his most conciliatory speeches to date in January 1984, when he imagined an American couple and a Russian couple sitting down together and discovering their shared humanity - a mutual love of family, home, and above all peace. He also continued his effort to engage with his Soviet counterparts through personal letters. But there was no stability of leadership in the Kremlin. Leonid Brezhnev passed away in November 1982; Yuri Andropov died in February 1984, and his successor, Konstantin Chernenko, followed him just over a year later in March 1985. 'How am I supposed to get anyplace with the Russians', Reagan asked 
his wife Nancy, 'if they keep dying on me?' ${ }^{12}$ Fortunately for the President, a fourth Soviet leader who was actually interested in dialogue stuck around long enough for them to meet.

\section{GENEVA: A SPARK OF MUTUAL TRUST}

Mikhail Gorbachev was appointed General Secretary on 11 March 1985. Born in 1931, he was a generation younger than his predecessors, as well as most of the Politburo, and also twenty years junior to Reagan. Gorbachev was the first Soviet leader not to have served in the Great Patriotic War. In place of the national trauma of Hitler's 'surprise attack' in 1941, the formative political influence on him was Khrushchev's 'secret speech' of 1956 revealing the grim excesses of Stalinism. Another significant experience was the travels to the West that Gorbachev undertook the 1970s and early 1980s, which opened his eyes to the limitations of the Soviet system and the need for 'new thinking'. He prized empirical knowledge above party dogma and turned for guidance to critics of Soviet foreign policy like the well-travelled Aleksander Yakovlev and intellectuals from the International Department of the Central Committee such as Anatoly Chernyaev, who became his principal foreign-policy adviser in February 1986. Gorbachev was the first universityeducated general secretary, with a degree in law; his wife Raisa lectured in sociology. Although Gorbachev remained rooted in Marxist-Leninism, he believed that the existing Soviet system had failed to deliver the goods, both literally and metaphorically. He was especially impressed by Scandinavian models of social democracy and sought to emulate

\footnotetext{
12 Ronald Reagan, An American Life (New York, 1990), 611.
} 
their ideas and practices without, however, fully rejecting collectivist philosophy. Like Reagan, he was therefore a man of paradox - a product of his own society who was nonetheless ready to think heretically. ${ }^{13}$

Taking advantage of Chernenko's funeral, Reagan sent Vice-President George H. W. Bush with a letter inviting the new Soviet leader to meet him in Washington at the 'earliest convenient opportunity'. ${ }^{14}$ Although in his reply Gorbachev evaded the question of venue, he expressed complete agreement that a summit was desirable, though in the form of 'a meeting to search for mutual understanding on the basis of equality' rather than necessarily concluding 'some major documents'. Gorbachev began to consolidate his control over Soviet foreign policy. A crucial step at the end of June was the replacement of the veteran hardliner Gromyko (known to the Americans as 'Grim Grom') with Eduard Shevardnadze, the communist party leader in Georgia whose lack of foreign policy experience and reliance on Gorbachev's patronage made him a reliable lieutenant. He was also far more open than his predecessor. 'I like it when a person does business with a smile and gets the point of a witty remark', Shevardnadze observed, in a clear dig at his predecessor. 'We achieve little with dour solemnity and immobile facial muscles'. ${ }^{15}$

\footnotetext{
${ }^{13}$ Archie Brown, 'The Gorbachev revolution and the end of the Cold War', in Melvyn P. Leffler and Odd Arne Westad, eds, The Cambridge History of the Cold War, vol. 3, (Cambridge, 2011), 244-66.

${ }^{14}$ Letter, Reagan to Gorbachev, 11 March 1985, 1, http://www.thereaganfiles.com/19850311.pdf.

${ }^{15}$ Asked on one occasion by American diplomat whether he had enjoyed his breakfast, Gromyko replied 'Perhaps'. See Wilson, The Triumph of Improvisation, at 93.
} 
For now, however, the new leader's priority was domestic reform. At his nomination, a Politburo member declared that change was imperative: 'we cannot postpone questions of economic development - they will not wait.. ${ }^{16}$ But the Soviet Union had fallen behind economically not just because of an outmoded and industrial base but also because 20 or 30 per cent of gross domestic product was diverted to military ends. ${ }^{17}$ Hence Gorbachev's desire to reduce Cold War tensions.

The balance of power in Washington was also tilting in favour of dialogue. All through Reagan's first term hawks in the Pentagon and National Security Council (NSC) had encouraged a policy of confrontation. But after the president's re-election in November 1984 he felt politically freer to pursue his inclinations for quiet diplomacy. The White House believed that the United States was now in a stronger bargaining position thanks to Alliance solidarity, the successful Cruise and Pershing deployments, and Soviet alarm at SDI. ${ }^{18}$ At the same time Shultz was gradually gaining the upper hand in his battle to wrest control of Soviet-American relations into the hands of the State Department. An economist by training and an experienced business leader, Shultz knew how to combine toughness with negotiation - both with the Soviets and in the bear-pit of Washington politics.

\footnotetext{
${ }^{16}$ Minutes, CPSU Politburo session, 11 March 1985, History and Public Policy Program Digital Archive, TsKhSD, F.89, http://digitalarchive.wilsoncenter.org/document/120771.

${ }^{17}$ Stephen Kotkin, Armageddon Averted: The Soviet Collapse, 1970-2000 (New York, 2008), 61; Emily Rosenberg, 'Consumer Capitalism and the End of the Cold War', in Leffler and Westad, The Cambridge History of the Cold War, vol. 3, 489-512.

${ }^{18}$ RRPL, Robert McFarlane files, RAC box 1, NSDD-153: Shultz-Gromyko meeting, 1 January $1985,1$.
} 
'Strength and realism can deter war', he told senators in 1983, 'but only direct dialogue and negotiation can open the path to lasting peace'. He also favoured making incremental progress in Soviet-American relations wherever possible - rejecting the Nixon-Kissinger tactic of strict 'linkage' between issues whereby progress in one area was contingent on progress in the others. In January 1985, even before Gorbachev gained power, Shultz persuaded the Soviets to resume arms control negotiations in Geneva, which they had so abruptly abandoned fourteen months earlier. His determined pursuit of diplomatic opportunities and his growing rapport with Shevardnadze established a vital back-channel between Washington and Moscow.

Reagan and Gorbachev's readiness to meet built on this new thaw in SovietAmerican relations. In contrast with the Brezhnev-Gromyko era, Gorbachev saw summitry as a vital opportunity for mutual reconnaissance between two leaders rather than a carefully-scripted moment of political theatre to consummate a long diplomatic negotiation. Reagan shared his faith in the value of personal contact at the top. But this was a high-risk business. The White House was particularly concerned to dampen public expectations that the summit would produce a dramatic breakthrough. ${ }^{19}$ The Soviet leader remained unwilling to go Washington - that would seem too much like being America's poodle - so they eventually settled on Geneva, in neutral Switzerland, as a mutually acceptable venue reflecting their equality as superpowers.

\footnotetext{
${ }^{19}$ Matlock, Reagan and Gorbachev, 149.
} 
The two sides approached the summit with different goals in mind. The Kremlin tried to resist American efforts to get human rights and regional conflicts on the agenda but Reagan kept pursuing these issues, speaking to the UN in October about 'a broader vision of world leadership' that went 'beyond arms control' to truly reflect 'Western ideals'. ${ }^{20}$ Moscow wanted to keep the focus of the summit on the arms race, with Gorbachev waging a 'star peace' campaign to depict SDI as the lone obstacle to nuclear arms control. A new and dynamic radicalism was now transforming Soviet foreign policy. Chernyaev had outlined its thrust as early as 1982: withdrawal from Afghanistan, non-intervention in Eastern Europe, removal of European SS-20s, military cuts, and more open borders. ${ }^{21}$ Summitry was deemed critical to the success of this diplomatic grand design. Yakovlev counselled Gorbachev that Reagan wanted to be remembered as a 'great peace-maker President' and encouraged him to 'get a personal impression' of Reagan in Geneva. As a test, Gorbachev proposed a 50 per cent cut in both sides' nuclear arsenals if the United States would abandon Star Wars. Such a concession was inconceivable in Washington but the Reagan Administration was not of one mind on how to exploit SDI. Defense Secretary Caspar Weinberger and CIA Director William Casey - both viscerally suspicious of the USSR - insisted that weapons programmes, especially SDI, were non-negotiable, whereas Shultz wanted to keep them up his sleeve as possible 'bargaining chips'. ${ }^{22}$

\footnotetext{
${ }^{20}$ RRPL, Jack Matlock files, box 45, Scope paper, Shultz to Reagan: UNGA, 7 October 1985.

${ }^{21}$ Grachev, Gorbachev's Gamble, 39, 53.

${ }^{22}$ RRPL, Jack Matlock files, box 45, Letter, unknown to Matlock: NSC meeting on Shevardnadze, undated.
} 
Characteristically Reagan was reluctant to arbitrate the 'many irreconcilable differences', leaving U.S. policy in this vital area inchoate. ${ }^{23}$

Both leaders approached the summit in a mood of uncertainty, struggling to decipher each other's mixed signals. Gorbachev had admonished Reagan back in March that 'trust is an especially sensitive thing', which would 'not be enhanced, for example, if one were to talk as if in two languages: one for private contacts and the other, as they say, for the audience'. Here was a clear reference to the grating dissonance of the two Reagans the would-be diplomatist and the strident ideologue. ${ }^{24}$ The American failure to come up with a draft communiqué in advance of the summit, due to the bureaucratic infighting over SDI, aroused particular suspicion in Moscow; it seemed to suggest that the United States was not serious about the meeting. In Washington, those prepping the President for the summit highlighted similar contradictions in their adversary. Veteran diplomat Jack Matlock, now a senior adviser in the NSC, diagnosed a split Soviet personality that would 'lie and cheat' or 'stonewall a negotiation,' but could also be 'candid to a fault - grovelling in his nation's inadequacies'. (Reagan called Matlock's essay 'one of the best things I have read on the Soviet Russian psychology'..25 For his part Shultz depicted Gorbachev as a

\footnotetext{
${ }^{23}$ RRPL, Jack Matlock files, box 50, memorandum, MacFarlane to Reagan, 'How to record the summit?' 12 November 1985.

${ }^{24}$ Letter, Gorbachev to Reagan, 24 March 1985, 3, NSAEBB no. 172, doc. 6 http://nsarchive.gwu.edu/NSAEBB/NSAEBB172/Doc6.pdf.

${ }^{25}$ RRPL, Jack Matlock files, box 49, Marginalia, McFarlane to Reagan: Soviet Union, 27 September 1985, Report: Soviet psychology, undated.
} 
'curious blend of new and old', ready for reform but 'not about to squander the legacy of Soviet power' ${ }^{26}$ Lessons from previous Cold War encounters were not deemed encouraging: Kenneth Adelman, director of the Arms Control and Disarmament Agency, judged summits a 'risky business at best' that had 'clearly not helped moderate Soviet behavior'. ${ }^{27}$ On the summit's eve, neither side entertained high expectations, though Shultz had at least managed to secure a more united American delegation by keeping the everobstructive Weinberger off the plane. ${ }^{28}$

The long awaited encounter took place in Geneva from 19 to 21 November 1985, in the full glare of the world's media. (Almost all the city's 12,000 hotel rooms had been booked for months and the Americans took over the entire 500-room Intercontinental for staffers and the White House press corps. ${ }^{29}$ ) The Americans hosted the first day's meetings in a private villa on Lake Geneva; on the second day the leaders moved downtown to the Soviet Embassy. The summit combined plenary meetings - featuring long and often formulaic statements, especially by Reagan - with informal one-on-one encounters that

\footnotetext{
${ }^{26}$ RRPL, Donald Regan files, box 7, Memorandum, Shultz to Reagan: What to expect from Gorbachev, 14 November 1985.

${ }^{27}$ RRPL, Jack Matlock files, box 47, Memorandum, Matlock to McFarlane: Adelman memo, 3 July 1985; and Memorandum, Kenneth Adelman to McFarlane: US-Soviet leadership meetings (underlining in the original).

${ }^{28}$ On Weinberger's spoiling tactics, see Shultz, Turmoil and Triumph, 578-82, 598; Wilson, The Triumph of Improvisation, 95.

29 'The summit: What it's all about - the city gets ready', New York Times, 18 November 1985, A6. For fuller discussion of the Geneva meeting, see Reynolds, Summits, 339-54.
} 
were mediated only by interpreters. The public face of each leader was on display in the plenaries, as Reagan and Gorbachev indulged in ideological sloganeering and dug in on entrenched positions - human rights for Reagan, SDI for Gorbachev. Debate on the latter issue became particularly intense on the second day, with the Soviet leader insisting that SDI could allow the Americans to mount a first strike on the USSR and Reagan reiterating his mantra that SDI would be a 'shield' not a 'spear'. 'Do you take us for idiots?' Gorbachev exploded at one point. Ironically the novelty of using simultaneous translation in the plenaries, which speeded up business and more naturally connected words to body language, also allowed the exchanges to become more heated with Gorbachev frequently cutting in before Reagan's translator had finished. ${ }^{30}$ [place Figure 6.2.here]

Ultimately the plenaries mattered less than the personal tête-à-têtes, all of which overran their allotted time because the two men were surprised to find that they clicked. Chatting on day one before a roaring fire in a pool-house overlooking Lake Geneva (see Figure 6.2), Gorbachev began to grasp 'on a human level' Reagan's utopian hopes for SDI, while also getting across his own passionate fear of 'starting an arms race in a new sphere'. By the time they left the poolhouse they had agreed - to the delight of Shultz - to further summits in Washington and Moscow. ${ }^{31}$ As they parted on the first evening, the two men

\footnotetext{
${ }^{30}$ Third Reagan-Gorbachev plenary meeting, 20 November 1985, NSAEBB no. 172, doc. 21, http://nsarchive.gwu.edu/NSAEBB/NSAEBB172/Doc21.pdf. See also Reynolds, Summits, 350-1.

${ }^{31}$ Shultz, Turmoil and Triumph, 601. In a briefing paper for the president, Shultz suggested that reaching agreement for follow-up summits in Moscow and Washington might be 'the most important outcome of this
} 
'locked hands and eyes with real affection'; according to Reagan's official biographer: 'I have rarely seen such mutuality.' Gorbachev remembered what he called a 'spark of electric mutual trust which ignited between us, like a voltaic arc between two electric poles'. The President also responded on a human level. 'You could almost get to like the guy', the President admitted that evening to his Chief of Staff Don Regan. ${ }^{32}$ At the end of the summit the two leaders issued a joint statement that 'nuclear war cannot be won and must never be fought' - Reagan's formulation, which Gorbachev had embraced. ${ }^{33}$ None of this overrode each man's fierce ideological commitment, or their frequent mutual frustration Gorbachev being particularly prone to fume about the 'banalities' that Reagan often uttered. Yet that spark of mutual trust was never truly extinguished.

\section{REYKJAVIK: THINKING THE UNTHINKABLE}

By the criteria that the Americans had set beforehand - 'to establish personal contact and, if possible, to develop an agenda for negotiations' - Geneva proved a success. ${ }^{34}$ White House

summit as it could establish a process of decision-making'. RRPL, Robert E. Linhard files, box 92178:

Summit Nov. 19-21, folder 1, Shultz, Meeting with the President, 6 November 1985, 2.

${ }^{32}$ Edmund Morris, Dutch: A Memoir of Ronald Reagan (New York, 1999), 568-9, 823; Gorbachev's postsummit comments are noted in the diary of Anatoly S. Chernyaev, 24 November 1985, NSAEBB no. 172, doc. 26, http://nsarchive.gwu.edu/NSAEBB/NSAEBB172/Doc26.pdf.

${ }^{33}$ RRPL, Robert E. Linhard files, RAC box 11, Letter, Reagan to Gorbachev: The inadmissibility of nuclear war and other principles, 31 November 1985.

${ }^{34}$ RRPL, Jack Matlock files, box 50, NSDD-183: Geneva meeting, 8 August 1985, 1. 
officials wanted to schedule the second summit expeditiously on the assumption that 'momentum' was now with them. ${ }^{35}$ Gorbachev was more ambivalent. He praised 'the Spirit of Geneva' but complained that Reagan had been facile and intransigent. ${ }^{36}$ To increase the pressure on the White House, on 15 January 1986 he publicized a three-stage plan to eliminate nuclear weapons by the new millennium. The superpowers would sign a Comprehensive Test Ban Treaty (CTBT), halve their strategic arsenals, and drastically reduce INF forces. Britain, France, and China would then join them in multilateral talks to shrink nuclear forces worldwide. The process would culminate with the international community formalizing the abolition of nuclear weapons in a treaty. ${ }^{37}$ Reagan admitted that the speech was, 'at the very least,' one 'hell of a propaganda move', but he disliked being upstaged and resented Gorbachev giving him only one day's advance notice. ${ }^{38}$ The president stopped handwriting his letters to Gorbachev to get across 'without saying so, that the use of proposals for propaganda is not helpful' ${ }^{39}$

\footnotetext{
${ }^{35}$ RRPL, Jack Matlock files, box 53, Memorandum, Michael Schneider to USIA Director: Forward from Geneva, 1, 5 .

${ }^{36}$ Diary entry, Chernyaev, 24 November 1985 , NSAEBB no. 172 , doc. 26 , http://nsarchive.gwu.edu/NSAEBB/NSAEBB172/Doc26.pdf

${ }^{37}$ Hoffman, The Dead Hand, 235, 237.

${ }^{38}$ Ronald Reagan, The Reagan Diaries (New York, 2007), 383.

39 'Memorandum, Poindexter to Reagan, Gorbachev's handwritten letter, 15 February 1986', copy at http://endofcoldwarforum.org/sites/default/files/docs/reagan/STY-1986-02-15.pdf
} 
Gorbachev's demarche shrewdly exploited a deepening defence debate within NATO, exacerbated by SDI. Multilateralists in Washington such as Reagan's arms control fixer Paul Nitze wanted to maintain a balance of terror based on credible deterrents for both sides. ${ }^{40}$ Unilateralists such as NSC staffer Robert Linhard believed that stability would be achieved by making SDI 'as effective as possible as soon as possible'. ${ }^{41}$ Western European allies, most vocally British Prime Minister Margaret Thatcher, sided with Nitze, dismissing anti-ballistic missile (ABM) systems as too speculative to rely upon and, if ever implemented, likely to decouple American security from that of Western Europe.

The debate also had a very public dimension. As early as April 1982 an NSC report pinpointed mushrooming antinuclear sentiment in Europe and America as 'the most important national security opportunity and challenge of this Administration' ${ }^{42}$ Both SDI and START were therefore deliberately framed as steps towards nuclear disarmament. But this did not quell the growing movement for a nuclear 'freeze' which, by 1986, was attracting significant support from mainstream religious organizations in the United States. To counter Gorbachev's peace campaign the NSC recommended an American declaration renouncing first use of nuclear weapons, on the grounds that this was 'near and dear to the

\footnotetext{
${ }^{40}$ RRPL, Robert E. Linhard files, RAC box 6, Memorandum, Paul Nitze: Transition to defense, 4 April 1985, $2-3$.

${ }^{41}$ RRPL, Robert E. Linhard files, RAC box 6, Email, McFarlane to Linhard: SDI, 30 March 1985.

${ }^{42}$ RRPL, Robert McFarlane files, RAC box 1, Memorandum, William Clark to Reagan: The anti-nuclear movement, 22 April 1982, 4.
} 
hearts of disarmamenters and Catholic Bishops' ${ }^{43}$ But Reagan's attitude to anti-nuclear feeling was more sympathetic. Shultz told one British official that even though many US 'arms control experts' belittled abolition, the president shared the 'growing unease' about nuclear weapons and was seeking a 'stable pattern within which to reduce them. ${ }^{44}$ At a National Security Planning Group meeting in February, Reagan rebuffed Weinberger and other hawks when they dismissed Gorbachev's disarmament plan as a 'publicity stunt', ordering a response that 'we share their overall goals' and 'now want to work out the details'. ${ }^{45}$

Early planning for Gorbachev's American summit envisaged a grand tour of the United States from Washington to Los Angeles. ${ }^{46}$ But that was before the Chernobyl disaster changed the terms of debate. The disastrous meltdown at the Ukrainian nuclear power plant on 26 April 1986 was the worst civilian nuclear accident of the Cold War era, releasing over four hundred times more radioactive material than the bomb dropped on Hiroshima in 1945, with fallout spreading across much of Eastern and Central Europe from the Baltic to the Mediterranean. Equally damaging for the Kremlin was the fact that the

${ }^{43}$ RRPL, Robert E. Linhard files, RAC box 9, Memorandum, Judy Mandel to Stephen Sestanovich: Initiative, 27 January 1986.

${ }^{44}$ RRPL, Robert E. Linhard files, RAC box 12, Cable, Shultz to London: British on Reykjavik, 25 October $1986,3$.

${ }^{45}$ Reagan, The Reagan Diaries, 388.

${ }^{46}$ RRPL, W. Dennis Thomas files, box 7, Memorandum, Henkel to Regan and Poindexter: President's views - Summit II, 2 April 1986, 1. 
first significant information about the scale of the disaster came from Sweden and was not officially acknowledged in Moscow for several days. The impact of the disaster on Gorbachev and like-minded colleagues was immense. 'Just a puff and we can all feel what nuclear war would be like', he told the Politburo. He asked them to imagine what a real nuclear war 'would mean for Europe with its concentration of population' ${ }^{47}$

Chernobyl injected new passion into Gorbachev's quest to abolish nuclear weapons. It also underlined the importance of his policy of glasnost - variously translated as openness, transparency, or even freedom of information - to appease critics of the Chernobyl cover-up at home and abroad. Yet he was also increasingly alarmed at the hawkish rhetoric from the president and his advisers, intended in part to resist Congressional attempts to rein in defence expenditures by fanning the flames of domestic anti-communism. The Soviet leader feared, in short, that the spirit of Geneva was evaporating fast and the consequences of inaction for the USSR would be grave. 'If we do not compromise now on some questions, even very important ones', Gorbachev warned his foreign policy advisers, 'we will be pulled into an arms race beyond our power, and we will lose this race, for we are presently at the limit of our capabilities.' His plan, outlined by Chernyaev, was for mutual 50 per cent cuts in all types of nuclear weapons, giving priority to the removal of all Soviet-American INFs from Europe. The Pershing IIs, he asserted,

\footnotetext{
${ }^{47}$ Archie Brown, The Gorbachev Factor (Oxford, 1996), 163; Wilson, The Triumph of Improvisation, 105-6.
} 
were like 'a gun pressed to our temple'. On a larger plane, Gorbachev made clear that 'my ultimate goal is the liquidation of nuclear weapons' ${ }^{48}$

These concerns lay behind the letter that the Soviet leader sent to Reagan on 15 September 1986. He proposed ‘a quick one-on-one meeting' in Iceland or London, perhaps for just a single day, in order to generate 'instructions to our respective agencies on two or three very specific questions, which you and I could sign during my visit to the United States'. The questions Gorbachev identified were (i) extending the duration of the ABM treaty of 1972 and strengthening its content, especially by restricting R\&D on space weapons to 'laboratories'; (ii) accepting the Soviet INF proposals for the 'complete elimination' of Soviet and American medium-range missiles in Europe, and (iii) agreeing to a complete moratorium on nuclear testing. There had been 'no movement on these issues' since Geneva, Gorbachev argued, and everything would 'continue to mark time' unless the two of them provided 'a major impetus' from the very top 'to demonstrate political will' ${ }^{49}$

Historian James Graham Wilson has observed that Gorbachev's letter offered Reagan more Soviet concessions 'than in the entirety of his presidency up to that time'. But Washington does not seem to have appreciated just how serious and radical Gorbachev was. Discounting his concrete proposals, the NSC complained of the Soviet leader's 'coyness' about his real intentions and advised the President to 'smoke him out in your discussions'.

\footnotetext{
${ }^{48}$ Anatoly Chernyaev notes, 4 October 1986, NSAEBB, no. 203, doc. 5, http://nsarchive.gwu.edu/NSAEBB/NSAEBB203/Document05.pdf.

${ }^{49}$ Gorbachev to Reagan, 15 September 1986, NSAEBB no. 203, doc. 1 , http://nsarchive.gwu.edu/NSAEBB/NSAEBB203/Document01.pdf.
} 
Shultz saw the offer of a meeting as evidence that Reagan's policy of negotiation from strength was paying off. Their aim, he said, should be 'to produce substantive progress (but no agreements per se) at Reykjavik that will enhance the chances for a successful summit in the U.S.' He wanted the agenda to highlight two issues: arms control, especially START, and human rights. The Americans clearly approached Reykjavik as a preparatory meeting for the real 'summit' in the United States. No one foresaw the drama that would ensue in Iceland..$^{50}$

Reagan and Gorbachev met at Höfði, a government guesthouse just outside the windswept Icelandic capital, on 11 October. The venue was secluded but cramped: for one presidential briefing, American staffers had to use a tiny upstairs bathroom, with three senior aides standing in the tub. When Reagan walked in he said, 'I'll take the throne' and sat on top of the toilet. ${ }^{51}$ Unlike Geneva, Reykjavik was intended as a strictly business affair, mainly one-on-one. But it went beyond the single day originally envisaged because the four plenary meetings and related discussions among advisers gained a momentum of

\footnotetext{
${ }^{50}$ Wilson, The Triumph of Improvisation, 111; Shultz to Reagan, memo: Reykjavik, 2 October 1986, NSAEBB no. 203, doc. 2, http://nsarchive.gwu.edu/NSAEBB/NSAEBB203/Document02.pdf; and NSC: Gorbachev's Goals and Tactics at Reykjavik, 4 October 1986, NSAEBB no. 203, doc. 6 , http://nsarchive.gwu.edu/NSAEBB/NSAEBB203/Document06.pdf. See also RRPL, Jack Matlock files, box 56, Memorandum, Matlock, Linhard and Tyrus Cobb to Poindexter: Points to raise with president on Reykjavik themes, undated.

${ }^{51}$ Nicholas Thompson, The Hawk and the Dove: Paul Nitze, George Kennan, and the History of the Cold War (New York, 2009), 305.
} 
their own focusing, under the stimulus of Gorbachev's radical package, largely on arms control - contrary to the wider American agenda. At the first session the Soviet leader proposed a mutual 50 per cent cut in strategic nuclear forces, the 'complete elimination' of Soviet and American INFs in Europe, and total adherence to the ABM treaty of 1972 for at least another ten years, followed by a period of three to five years in which the two superpowers would negotiate about how to proceed. During this interval, R\&D into space weapons would not be conducted 'outside of laboratories'. ${ }^{52}$ Without this last provision, as Gorbachev's briefing papers noted, 'it would be impossible for the Soviet Union to reduce its strategic nuclear forces because that would objectively help the United States to achieve a decisive military advantage over us'. The Soviets did not expect to strangle SDI completely but wanted to prevent the Americans from using their head-start in space weaponry to extract concessions from the USSR in nuclear arms talks. 'If the United States does not test these weapons over the next 10 years, that will allow us to decrease our lag behind them in creating the space-based echelon of ABM defense'. Seeing SDI in this overall context of linked diplomatic bargaining Gorbachev was therefore adamant that the 'package' has to be accepted as a whole: his offer of radical arms cuts was conditional on Reagan accepting a brake on SDI. ${ }^{53}$

\footnotetext{
${ }^{52}$ US Memcon, Reagan-Gorbachev, first meeting, 11 October 1986, 6-8, NSAEBB no. 203, doc. 9, http://nsarchive.gwu.edu/NSAEBB/NSAEBB203/Document09.pdf.

53 'Memoranda from Vitalii Kataev, no date', in Sidney D. Drell and George P. Shultz, eds, Implications of the Reykjavik Summit on its Twentieth Anniversary (Stanford, CA, 2007), 64, 77.
} 
Nitze, whose government service stretched back to the Second World War, called the Soviet proposal 'the best we have received in 25 years' ${ }^{54}$ But to Gorbachev's chagrin, Reagan did not respond enthusiastically in the first session. Sticking to his prompt cards, he reiterated his commitment to the principle of SDI and emphasized that any INF deal must take account of such weapons in Asia as well. The President also highlighted the issue of verification, trotting out a Russian proverb he had recently learned, 'doveryai no proveryai' - 'trust, but verify' - which would become his mantra. ${ }^{55}$ After a lunch break that afforded the Americans time to assess Gorbachev's proposals, the two men got down to details. Reagan said that they would accept a mutual zero in Europe on INFs if an acceptable deal was also reached on INFs in Asia. Gorbachev was receptive. On what the Soviet leader called 'space weapons' Reagan kept insisting that SDI was a peaceful technology that the United States was ready to share. This inflamed the nerve Reagan had touched in Geneva. 'Excuse me, Mr President', Gorbachev finally exploded: 'You are not willing to share with us oil well equipment, digitally guided machine tools, or even milking machines. Sharing SDI would provoke a second American revolution! Let's be realistic and pragmatic'.$^{56}$ Despite this outburst, the leaders set up two working groups of staff to work through specific problem. One group dealt with arms control, the other with a range of diplomatic issues including human rights, regional conflicts, and improved contacts and

\footnotetext{
${ }^{54}$ Thompson, The Hawk and the Dove, 303.

${ }^{55}$ US Memcon, Reagan-Gorbachev, first meeting, 11 October 1986, 3-4, NSAEBB no. 203, doc. 9, http://nsarchive.gwu.edu/NSAEBB/NSAEBB203/Document09.pdf

${ }^{56}$ Matlock, Reagan and Gorbachev, 222-3.
} 
communication. While the latter group finished its work by midnight, the arms controllers Nitze and his Soviet counterpart, Marshal Sergei Akhromeyev - laboured until four in the morning, as the Americans tried to pick apart what the Soviets kept insisting was a single package. Although the two sides moved closer to the idea of a 50 percent cut in strategic forces, the Soviets linked this to agreement on controlling the testing of SDI. 'We brought closer our positions on strategic weapons quite well', a weary Akhromeyev summed up, 'but completely disagreed on the ABM. This makes strategic weapons reductions impossible ... Regretfully our work today did not lead to big results' ${ }^{57}$

The next morning, at the start of a session that ran from 10.00 am until $1.35 \mathrm{pm}$, Gorbachev complained that the Americans seemed resistant to his offers. The United States 'did not appear to feel obliged to take Soviet concerns into account, while the Soviets had met American concerns'. On INFs, they agreed on a zero option for Europe and 100 missiles each in Asia. But on SDI the two leaders dug in, with Reagan quoting Marx and Lenin and Gorbachev fuming about the President's 'evil empire' rhetoric. In desperation, Shevardnadze asked if they could at least reach an agreement about the duration of the ABM treaty but Gorbachev cut that off: 'I made a specific package proposal, and I would ask you to treat it as such'. Reagan inquired whether all the progress they had made should be thrown away because of this Soviet insistence on linkage. ${ }^{58}$

\footnotetext{
${ }^{57}$ Memcon, Akhromeyev-Nitze working group meeting, 11-12 October 1986, 52, NSAEBB no. 203, doc. 17, http://nsarchive.gwu.edu/NSAEBB/NSAEBB203/Document17.pdf.

${ }^{58}$ Matlock, Reagan and Gorbachev, 225; US MemCon, Reagan-Gorbachev third meeting, 12 October 1986, 7, 16-17, NSAEBB no. 203, doc. 13, http://nsarchive.gwu.edu/NSAEBB/NSAEBB203/Document13.pdf.
} 
After a cursory survey of the other working group's suggestions, they agreed to pause for thought and re-convene in mid-afternoon. The discussions resumed at 3.25, only for the Americans to take an hour-long break at 4.30 as they tried to come up with a form of words that would satisfy Gorbachev's concerns about confining the testing of SDI to 'laboratories'. Shultz, Nitze, and Adelman wanted to meet him halfway, but National Security Adviser John Poindexter and Assistant Secretary of Defense Richard Perle would not budge..$^{59}$ Eventually the American group settled on the 10-year timeframe for respecting the ABM treaty but refused to limit SDI R\&D to laboratories; at the end of the ten years 'either side could deploy [space-based] defenses if it so chose'. ${ }^{60}$ They also switched what would be eliminated during years five to ten from 'strategic offensive arms' to 'offensive ballistic missiles' - probably to retain US advantages in cruise missiles and long-range bombers.

When the leaders reconvened at 5.30, there ensued an increasingly frazzled discussion between men who were now teetering between exhilaration and exhaustion. From the minutes it is unclear whether they were talking about eliminating strategic weapons, ballistic missiles, or nuclear weapons as a whole. But ultimately neither leader would budge on what both agreed was 'one word' - 'laboratories'. Gorbachev insisted it was 'unacceptable' for him to offer 'deep reductions in nuclear weapons' while allowing the Americans to 'conduct all sorts of research that would go against the ABM Treaty, and

\footnotetext{
${ }^{59}$ RRPL, Al Keel files, RAC box 2, Email, Linhard to Poindexter: Update on arms control, 24 October 1986.

${ }^{60}$ RRPL, Al Keel files, RAC box 3, Notes, US remark of Soviet counter, undated.
} 
put weapons in space': he would be denounced at home as a 'dummy' (durak). The President responded in kind, as 'one political leader to another'. If he did what Gorbachev asked, he would lay himself open to the extreme anti-Soviet right who were already 'kicking his brains out'. In the cold prose of the American minutes:

The President said that he could not give in.

Gorbachev asked if that was the last word.

The President said yes. ${ }^{61}$

Reykjavik's denouement obscured its momentousness. ${ }^{62}$ When cameras recorded the two leaders' haggard faces and tense body language as they left Höfði, a tragic requiem became the media's dominant theme. Privately, however, the participants, despite outbursts of anger, were hopeful. It was significant that Gorbachev chose not to heed instructions from the Politburo to 'make everything public' if Reagan refused to react positively. 'In no sense would I call Reykjavik a failure', Gorbachev told his team on the flight home. 'It is a step in a complicated and difficult dialogue. I am even more of an optimist after Reykjavik'. ${ }^{63}$ Reagan expressed similar sentiments. In a national address he portrayed himself as standing firm on human rights and SDI while proposing 'the most sweeping and

\footnotetext{
${ }^{61}$ US Memcon, Reagan-Gorbachev fourth meeting, 12 October 1986, 13-15, NSAEBB no. 203, doc. 15, http://nsarchive.gwu.edu/NSAEBB/NSAEBB203/Document15.pdf.

${ }^{62}$ Jonathan Hunt and Paul F. Walker, 'The Legacy of Reykjavik and the Future of Nuclear Disarmament', Bulletin of the atomic scientists 67, no. 6 (2011), 63-72.

${ }^{63}$ Grachev, Gorbachev's Gamble, 83; Notes, Chernyaev: Gorbachev's thoughts on Reykjavik, 12 October 1986, 1, NSAEBB no. 203, doc. 19, http://nsarchive.gwu.edu/NSAEBB/NSAEBB203/Document19.pdf.
} 
generous arms control proposal in history'. Although the Soviet had not accepted the American offer, he said 'we are closer than ever before to agreements that could lead to a safer world without nuclear weapons'. This was no mere rhetoric. Matlock concluded that 'the extent of agreement on key points was unprecedented'; according to Chernyaev, the meeting proved to Gorbachev that he and Reagan could 'do real business' together after all. ${ }^{64}$ At Reykjavik, the two leaders changed the whole tenor of the arms-control debate. By sharing their dream of a nuclear-free world, they had dared to think the unthinkable.

\section{WASHINGTON: DOING THE UNPRECEDENTED}

Once again, however, coming down from the summit proved an anti-climax - and an occasion for second thoughts. Gorbachev increasingly believed that Reagan 'was not free in making his decisions', opining that he and Shultz 'have their hands and feet tied by the military-industrial complex' ${ }^{65}$ The Soviet leader was also acutely conscious of the growing budget crisis in the USSR. So although remaining obdurate about his 'package' approach to arms control negotiations, he now shifted ground on restricting SDI R\&D to the

\footnotetext{
${ }^{64}$ Reagan, Address to the Nation on Reykjavik, 13 October 1986, APP website, http://www.presidency.ucsb.edu/ws/index.php?pid=36587\&st=\&st1. Matlock, Reagan and Gorbachev, 239; Grachev, Gorbachev's Gamble, 86.

${ }^{65}$ Notes, Chernyaev: Gorbachev's thoughts on Reykjavik, 12 October 1986, 1, NSAEBB no. 203, doc. 19, http://nsarchive.gwu.edu/NSAEBB/NSAEBB203/Document19.pdf; Notes, Chernyaev: Politburo session, 30 October 1986, 4, NSAEBB no. 203, doc. 23, http://nsarchive.gwu.edu/NSAEBB/NSAEBB203/Document23.pdf.
} 
'laboratory'. On 30 October, undeterred by dyspeptic comments from Gromyko, the Politburo agreed that it would accept testing anywhere except in space. There was a catch however. They would not disclose this new position to the Americans until the White House made clear its definition of 'laboratory'. ${ }^{66}$

In Washington, too, the autumn of 1986 was a time for second thoughts - or more accurately a counter-attack by hawkish critics of the President appalled at how far he had (nearly) gone. Neither quiet diplomacy nor top-level summitry had forged a consensus within the Administration or on Capitol Hill. Even the exact nature of what had transpired in Iceland was a matter of dispute. Reagan had been imprecise and inconsistent in his subsequent remarks to the nation, noting that ballistic missiles and SDI had been the main issues at stake before lamenting that 'all that work toward eliminating nuclear weapons' might 'go down the drain. ${ }^{67}$ To Thatcher, he recalled a proposal that would have halved all nuclear weapons and then eliminated ballistic missiles. The Washington Post quoted sources on Capitol Hill who recalled him praising nuclear abolition in front of members of

\footnotetext{
${ }^{66}$ Notes, Chernyaev: Politburo session, 30 October 1986, 4, NSAEBB no. 203, doc. 23, http://nsarchive.gwu.edu/NSAEBB/NSAEBB203/Document23.pdf.

${ }^{67}$ The NSC had tried to amend a sentence stating that SDI was 'the key to a world without nuclear weapons' to 'offens[iv]e ballistic missiles' but without success. RRPL, Robert E. Linhard files, RAC box 11, President's copy: Draft address to the nation on Iceland meeting, 13 October 1986, 3, 6, 10. Cf. Reagan, Address, Reykjavik, 13 October 1986, APP website, http://www.presidency.ucsb.edu/ws/index.php?pid=36587\&st=\&st1.
} 
the Congress. ${ }^{68}$ Seeking a clearer line while also trying to rein in his boss, Poindexter urged the President to 'step back from any discussion of eliminating all nuclear weapons' and instead focus on 'offensive ballistic missiles'. He warned that removing nuclear weapons from Europe would undermine Atlantic relations because NATO allies feared a costly transition to conventional defences and remarked how they were exhibiting 'new (and ironic) appreciation for SDI' after it had scuttled a disarmament deal in Iceland. ${ }^{69}$ Thatcher, in particular, was aghast at Reagan's anti-nuclear rhetoric. 'How could he do it?' she exclaimed. 'What is he doing?' Descending on the President at Camp David on 14 November with a draft in her handbag, she secured a joint statement affirming their commitment to the NATO's policy of nuclear deterrence. ${ }^{70}$

The Pentagon also did its best to turn back the clock on Reykjavik. Tipped off by a Soviet official that there was clear 'give' in Moscow on SDI, Shultz wanted to 'get away' from the word 'laboratory' and allow arms control negotiators in Geneva to discuss 'exactly what activities are permitted and what activities are prohibited under the ABM Treaty'. ${ }^{71}$ But Weinberger was unyielding. He took his reservations straight to Reagan -

\footnotetext{
${ }^{68}$ RRPL, Robert E. Linhard files, RAC box 12, Memcon, Reagan and Thatcher, 14 October 1986, 2-3; RRPL, Robert E. Linhard files, RAC box 11, Talking points: Reykjavik, 17 October 1986, 2.

${ }^{69}$ RRPL, Al Keel files, RAC box 3, Memorandum, Poindexter to Reagan: Why we can't commit to eliminating all nuclear weapons within 10 Years, 5-6 (underlining in the original).

${ }^{70}$ Charles Moore, Margaret Thatcher: The Authorized Biography, vol. 2 (London, 2015), 598, 609-10.

${ }^{71}$ RRPL, Al Keel files, RAC box 2, Memorandum, Shultz: Recommended next steps post-Reykjavik, 13 October 1986; Memorandum, Poindexter to Reagan: Where do we go from here?, undated, 1-3; RRPL, Al
} 
trivializing Soviet concessions, lambasting attempts to revise defence policy 'through the back door', and categorically rejecting any 'limitations' on SDI. ${ }^{72} \mathrm{He}$ and the Pentagon eventually prevailed. Shultz was instructed not to make the ABM Treaty 'more restrictive' than in 1972 and in consequence Shevardnadze never revealed that laboratories were no longer the Politburo's red line. ${ }^{73}$ In Gorbachev's eyes, Reagan seemed to be disavowing Reykjavik. The White House declared that it would stop abiding by the SALT II Treaty. Gorbachev protested 'not only that they are not doing anything in the spirit of Reykjavik, but they are removing all breaks from the arms race.' Financial considerations weighed heavily on him. Even a limited 'asymmetric' response to SDI would cost his government \$30-40 billion, when Moscow was already pouring \$4 billion per year into Afghanistan. Meanwhile he was under attack from the military who, he told the Politburo, were 'hissing among themselves' about the way he was supposedly 'disarming the country. ${ }^{74}$

Keel files, RAC box 3, Linhard, Memorandum for the Arms Control Support Group: Instructions re defense and space, 24 October 1986, 3.

72 RRPL, Al Keel files, RAC box 2, Memorandum, Weinberger to Reagan: Post-Reykjavik instructions for the Geneva negotiators, 19 October 1986.

${ }^{73}$ RRPL, Al Keel files, RAC box 2, Talking points, Shultz-Shevardnadze, 29 October 1986; Memorandum for Shultz: Your meetings with Foreign Minister Shevardnadze, undated; Draft instructions for NST delegation, Defense and space, 24 October 1986, 3; and, Email, Poindexter to Linhard: Shultz-Shevardnadze meeting, 28 October 1986.

${ }^{74}$ Grachev, Gorbachev's Gamble, 94, 109; Notes, Chernyaev on 'Politburo and Central Committee conference,' 1 December 1986, 1, NSAEBB no. 203, doc. 28, http://nsarchive.gwu.edu/NSAEBB/NSAEBB203/Document28.pdf. 
In an effort to impose a concerted policy in Washington, the NSC took firm control of preparations for presidential directive NSD 250 - even demanding that the draft be returned in a couple of hours to forestall stonewalling or fundamental criticisms. ${ }^{75}$ Entitled 'Post-Reykjavik Policy', NSD 250 turned the anti-nuclear radicalism of Reykjavik into more specific evolutionary plan for eventually eliminating ballistic missiles. Yet even this was controversial within the Beltway. The Joint Chiefs of Staff promptly responded that abolishing ballistic missiles would entail a massive compensatory increase in spending on conventional forces. ${ }^{76}$

NSD 250 was issued on 3 November 1986, only to be immediately overtaken by events. That same day news broke about a secret Administration operation to sell arms to Iran and then use the proceeds to finance anti-communist Contra guerrillas in Nicaragua both prongs of which violated Congressional legislation. By 25 November Poindexter had resigned in response to accusations that he had shred presidential documents; the scandal spread to finger Weinberger and even the President himself. Reagan was obliged to set up a special commission and, although not directly implicated in its findings, he formally apologized to the nation in a televised address in March 1987. The Iran-Contra affair - for a

\footnotetext{
${ }^{75}$ RRPL, Al Keel files, RAC box 2, Memorandum, Weinberger to Poindexter: Comments on your postReykjavik follow-up, 31 October 1986; NSSD 250: Post-Reykyavik policy, 3 November 1986, NSAEEB no. 203, doc. 25 http://nsarchive.gwu.edu/NSAEBB/NSAEBB203/Document25.pdf.

${ }^{76}$ RRPL, National Security Council: NSDD files, Executive Secretariat, box 91297, William Cockrell to Carlucci: JCS meeting with the President, 5 January 1987.
} 
time spoken of as a second Watergate - tarnished Reagan's hitherto 'Teflon' reputation and sapped the President's own morale.

Even more damaging for his presidency were the mid-term Congressional elections held on 4 November 1986. The Democrats extended their hold on the House of Representatives to a majority of eighty seats while also regaining control of the Senate with a ten-seat margin of 55 to 45 . Now that his opponents were in full control of Capitol Hill, Reagan feared that the days of generous funding for SDI were over. In desperation Weinberger vainly urged the President to approve immediate testing outside the laboratory and called for phased deployment as early as 1993. Despite all Weinberger's bluster, however, Reagan's was now a 'weakened presidency'. ${ }^{77}$

The implications of Iran-Contra and the Congressional elections were not lost on the Soviets. In a long memo on 25 February 1987 Yakovlev urged Gorbachev to exploit the diplomatic opportunity - in particular by 'untying' the arms control 'package' that the USSR had placed on the table at Reykjavik. The ideas in the package still worked, both as policy and as propaganda, Yakovlev contended, but "the "package" in its present form only ties our hands' because the Reagan Administration could represent it as 'our final position' and thereby continue the deadlock on arms control. The following day Gorbachev and the Politburo agreed to 'untie the package', planning a dramatic speech by the Soviet leader in mid-March to win over world opinion and kick-start negotiations. 'As difficult as it is to conduct business with the United States,' Gorbachev lamented, 'we are doomed to it. 'We

\footnotetext{
77 Wilson, The Triumph of Improvisation, 126-30.
} 
have no choice'. He cautioned his colleagues that 'we should not build our policy on illusions. We should not count on capitalism suffering an economic crisis', as MarxismLeninism predicted, adding that 'competition will continue in any case ... Our main problem is to remove the confrontation. That is the central issue of our foreign policy' ${ }^{78}$ The danger of American backtracking and the imperatives of Soviet reforms made limited arms control agreements more appealing. Gorbachev's domestic agenda was now moving into high gear. Sensitive to the drumbeat of American pressure on human rights, in December 1986 he had released the celebrated dissident Andrei Sakharov from house arrest. Gorbachev knew full well that Sakharov would now criticize the Soviet government relentlessly but his decision was a hugely symbolic signal to the West, addressing one of Reagan's major critiques of the 'evil empire'. Shevardnadze set up a human rights bureau in the Foreign Ministry and began to ease restrictions on the emigration of Soviet Jews. In January 1987 Gorbachev told the party plenum that the 'further democratization of Soviet society' was the most urgent task facing the CPSU. He also enlarged the concept of perestroika beyond its previous connotation of 'economic restructuring' to become the signature for his whole ethos of leadership. His book Perestroika: New Thinking for Our Country and the World, published in America on 3 November 1987, proved a global bestseller. It helped to disseminate his concepts of 'reasonable sufficiency' in weaponry, rather

\footnotetext{
${ }^{78}$ Alexander Yakovlev, 'Toward an analysis', 25 February 1987, 7, NSAEBB no. 238, http://nsarchive.gwu.edu/NSAEBB/NSAEBB238/russian/Final1987-02-25\%20Yakovlev\%20memo.pdf and Excerpt from Politburo discussions, 26 February 1987, 2, NSAEBB no. 238, http://nsarchive.gwu.edu/NSAEBB/NSAEBB238/russian/Final1987-02-26\%20Politburo.pdf.
} 
than an ever-accelerating arms race, and of a 'common European home' instead of a nuclear face-off across the iron curtain. In all these respects Gorbachev was strengthening his position for radical arms-control agreements, especially on theatre-nuclear forces in Europe. $^{79}$

Facing a Soviet leadership that was increasingly coherent and bold, Reagan's Administration remained divided and cautious. The key figure in brokering an eventual deal was George Shultz. In an effort to pick up the momentum after Reykjavik, he held direct talks with Gorbachev and the Soviet leadership on 13-14 April 1987. Shultz's trip aroused a storm of protest on Capitol Hill, already up in arms about sensationalized reports of Soviet spies infiltrating the U.S. Embassy in Moscow. Before the Secretary of State set off, Weinberger - playing his customary role as spoiler - had inveigled the president into signing instructions (immediately leaked to the press) that, in Shultz's words, were almost intended to ensure that 'I came back from Moscow without any progress toward an agreement' ${ }^{80}$

In Moscow he found Gorbachev at his most intemperate: 'I have an impression listening to you', he told Shultz, 'that you are walking around hot porridge and cannot make a decision to do anything'. Eventually their talks did make headway in three areas. Gorbachev agreed to a 'global zero' for intermediate-range nuclear forces, roughly 1,000 to 5,500 kilometres in range, thus covering Soviet and American arsenals in both Europe and

\footnotetext{
${ }^{79}$ Brown, The Gorbachev Factor, 122-6; Mikhail Gorbachev, Perestroika: New Thinking for Our Country and the World (New York, 1987).

${ }^{80}$ Shultz, Turmoil and Triumph, 884.
} 
Asia. Shultz wanted to include shorter-range INFs (SRINFs), from 500 to 1,000 kilometres in range, a category in which the USSR had some 160 missiles operationally deployed and the United States none at all. Gorbachev responded by proposing to abolish all SRINFs in Europe - an offer that greatly benefited the United States - but, because of his tight brief, Shultz was left in the embarrassing position of having to argue for the right to reach equality by build new American SRINFs. An incredulous Gorbachev exclaimed: 'But we want to eliminate these missiles', to which Shultz replied lamely: 'We want to have the right to have an equal level'. Gorbachev also proved surprisingly radical on verification an issue that had bedevilled the negotiation of SALT II in 1978-9. In the spirit of glasnost, he sketched out a comprehensive regime of on-site inspections that went further than the Americans were willing to go in return. In the light of his new 'reasonable sufficiency' thinking, with national security no longer seen as a zero-sum game, the precise size of the Soviet nuclear arsenal - so sensitive for his predecessors, haunted by 1941 - was no longer of decisive importance. ${ }^{81}$

Traditional Cold War axioms of military superiority were, however, still very much ascendant in Washington. Shultz returned from Moscow with the outlines of an INF deal, to which the President was receptive because of his need for a foreign-policy success to redeem the Iran-Contra debacle. But Shultz still had to battle with Administration hawks and opponents on Capitol Hill and to convince the President's alter ego that the Soviets

\footnotetext{
${ }^{81}$ Garthoff, The Great Transition, 312-13. Memcon, Gorbachev - Shultz meeting, 14 April 1987, 1-2, NSAEEB no. 238, http://nsarchive.gwu.edu/NSAEBB/NSAEBB238/russian/Final1987-04-14\%20GorbachevShultz.pdf.
} 
were serious. Privately Reagan assured his old friend William Buckley, a noted anticommunist ideologue, in May: 'I have not changed my belief that we are dealing with an "evil empire"'. And he kept up the propaganda war with a rousing speech in front of the Berlin Wall at the Brandenburg Gate on 12 June. Challenging the Soviet leader to show that perestroika and glasnost were more than 'token gestures', the President called for one 'unmistakable' sign of his commitment to 'freedom and peace': 'Mr Gorbachev, tear down this wall!' He had used this line many times before but repeated it in this headline-catching venue to show he was not a politically crippled president and to prove his continued toughness in dealing with Moscow. ${ }^{82}$

Shultz also had to secure the agreement of America's NATO allies for the 'doublezero' deal on INFs and SRINFs in Europe. Even though the British and French nuclear deterrents had always been excluded from bargaining, Thatcher deplored what she saw as an erosion of nuclear deterrence and it took until 12 June for NATO to approve. There followed a protracted wrangle about the SRINFs in West Germany - Pershing 1As - which Washington and Bonn regarded as 'German missiles' even though the United States owned and controlled their nuclear warheads. Chancellor Helmut Kohl eventually agreed in late August to eliminate the Pershing IAs as part of the overall settlement with the Soviets. Weinberger's Pentagon - obstructive to the end - had tried to get round this with the ploy

\footnotetext{
82 Reagan, Remarks at the Brandenburg Gate, 12 June 1987, APP website, http://www.presidency.ucsb.edu/ws/index.php?pid=34390\&st=\&st1; Wilson, The Triumph of Improvisation, 129; James Mann, The Rebellion of Ronald Reagan: A History of the End of the Cold War (London, 2009), 194-6.
} 
of converting Pershing II missiles into short-range Pershing IBs and turning them over to the Germans, but Kohl refused. ${ }^{83}$

Gorbachev was eager for a summit in America to sign the INF Treaty but he, too, had to square his conservative critics. Here luck played into his hands. On 28 May a singleengine plane had landed in the middle of Red Square and taxied to a stop in front of St Basil's Cathedral. The pilot was an eccentric West German teenager, Mathias Rust, who had improbably managed to evade all Soviet air defences along the way. This hugely embarrassing incident gave Gorbachev a pretext to 'retire' some 150 senior officers, from Defence Minister Marshal Sergei Sokolov downward - thereby removing (peacefully) a higher percentage of the Soviet military elite than in Stalin's notorious purge of 1937. In their place Gorbachev promoted more loyal and open-minded officers. ${ }^{84}$ On 9 July he secured Politburo approval for a double-zero on INFs and SRINFs in Europe and Asia, asserting confidently that this would 'make a strong impression in China, Japan, and the

\footnotetext{
${ }^{83}$ Garthoff, The Great Transition, 313-14; NSDD-278: Establishing a US negotiating position on SRINF missiles, 13 June 1987, NSAEBB no. 238, http://nsarchive.gwu.edu/NSAEBB/NSAEBB238/usdocs/Doc\%203\%20(Nat1\%20Sec\%20Decision\%20Direct ive\%2006.13.87).pdf; and State Department briefing papers: NST, START, INF, etc., 11 August 1987, NSAEBB no. 238, docs 4a-4e, http://nsarchive.gwu.edu/NSAEBB/NSAEBB238/.

${ }^{84}$ Wilson, Triumph of Improvisation, 134.
} 
whole of Asia ... We will get a huge political victory'. The new policy was announced two weeks later. ${ }^{85}$

Gorbachev also moved to staunch the 'bleeding wound' in Afghanistan - warning the Politburo that without decisive action the war might go on 'for another 20-30 years'. He therefore engineered a transfer of leadership in Kabul from communist strongman Babrak Karmal to Mohammed Najibullah, a moderate politician who, at Gorbachev's behest, embraced a policy of national reconciliation aimed at constructing a coalition government. ${ }^{86}$ When Shevardnadze visited Washington in mid-September, he told Shultz in confidence: 'We will leave Afghanistan. It may be in five months or a year, but it is not a question of it happening in the remote future. I say with all responsibility that a political decision has been made'. Shultz was acutely conscious that this was a 'dramatic moment' because the Kremlin's intervention in Afghanistan at Christmas 1979 had sparked the 'New Cold War' and had also proved a massive drain on national resources and psychology making Afghanistan the Soviets' equivalent of Vietnam. ${ }^{87}$

After Shevardnadze's visit, Shultz gained the President's approval to announce that the two superpowers had 'agreed in principle' to conclude an INF treaty and that this would probably be signed by the two leaders at a summit in Washington before Christmas. There was still significant criticism - Henry Kissinger for one complained that the deal 'undoes

\footnotetext{
${ }^{85}$ Excerpt from Politburo minutes, 9 July 1987, NSAEBB no. 238, http://nsarchive.gwu.edu/NSAEBB/NSAEBB238/russian/Final1987-07-09Politburo.pdf.

${ }^{86}$ Grachev, Gorbachev's Gamble, 105-10.

${ }^{87}$ Shultz, Turmoil and Triumph, 987.
} 
forty years of NATO' - but the pertinacious Secretary of State had won a major diplomatic victory. There was, however, a sting in the tail. Weinberger persuaded Reagan, schizophrenic as ever about the Soviets, to take a tough line on the rest of the arms control agenda, insisting on no compromises on strategic weapons or anti-missile defences. The Defense Secretary never trusted Gorbachev or believed he was sincere about reform. Weinberger's hardnosed approach to diplomacy was that if the Soviets made concessions, the Americans should simply increase the pressure, extract more, and give away nothing. 'No negotiations for two years', he told the President. Although Weinberger was now increasingly isolated and on the way out - he would resign in November, ostensibly on account of his wife's health - he had effectively ring-fenced START and SDI for the rest of Reagan's presidency. In October Gorbachev made his attendance at a summit conditional on American movement about strategic and space weapons but, faced with Washington's obduracy, he backed off. The INF deal was too important for him to risk derailment and he agreed to come to Washington in December to sign it. ${ }^{88}$

Washington was a different kind of Reagan-Gorbachev summit from its predecessors. Geneva and Reykjavik had been decisive moments in the Cold War - the first by sparking mutual engagement, the second in changing the terms of the whole nuclear debate. By contrast, the Washington summit of 7-10 December witnessed few breakthroughs: the hard work had been done via painstaking diplomacy over the previous

\footnotetext{
${ }^{88}$ Shultz, Turmoil and Triumph, 988 (Kissinger); Wilson, The Triumph of Improvisation, 129-30

(Weinberger).
} 
six months and the event itself was largely symbolic. Yet the symbolism was hugely important. Having dared to think the unthinkable at Reykjavik, the two leaders (now on first-name terms) had moved from thought to action in doing the unprecedented. For the first time in the Cold War the superpowers signed an agreement to reduce their nuclear arsenals, not merely setting a limit to further growth as Nixon and Brezhnev had done with SALT I. Moreover, they had agreed to eliminate a whole category of nuclear weapons that were especially feared for their quick-strike ability. Even though this amounted to only about five per cent of total nuclear stocks, it was a sign that the superpowers were capable of reversing their decades-long arms race. And the provisions for mutual verification, even inspections without notice, demonstrated a new level of mutual trust and openness. If anything Gorbachev, intoxicated by the spirit of glasnost, had proved more forthcoming on this issue than the Americans. The impression of new thinking was enhanced by his public relations offensive while in America. Images of an elegant and animated Soviet leader chatting with Steven Spielberg and Joe DiMaggio, or jumping out of his limo to press the flesh on a Washington street-corner, showed as vividly as the INF treaty that the Soviet Union was in the grip of revolutionary change.

\section{MOSCOW: AN UNFULFILLED CLIMAX}

The Soviets remained hopeful about further nuclear arms control. Gorbachev was keen to 'crown' the president's proposed visit to Moscow the following spring with 'an agreement 
on strategic offensive weapons' ${ }^{9}{ }^{89}$ But hardline elements in the NSC, CIA and the Pentagon had mobilized in opposition even before the Washington summit. A typical NSC paper presented Soviet concessions as intended to help Gorbachev 'consolidate his power, slow up our defense modernization and SDI programs, ease technology transfers, and split us from NATO'. NSC analyst Fritz Ermarth warned that a 'grand compromise' was afoot that could 'open the road' to 'a START deal in the spring, and a brilliant summit in Moscow'. He suggested that Frank Carlucci, Reagan's latest National Security Adviser, had ‘better preempt.${ }^{90}$ Carlucci, together with his deputy (and soon successor) Colin Powell wanted a 'hardheaded summit' that would focus on regional conflicts rather than arms control. Their aim was to slow down progress in discussing strategic and space weaponry, thereby making a Moscow 'coronation' unlikely. And they certainly did not want a repeat of Reykjavik, when the two leaders had taken the ball and run with it. NSC staffers therefore dreamed up 'a whole list of possible tricks for deflecting the momentum of conversation and buying

\footnotetext{
${ }^{89}$ Letter, Gorbachev to Reagan, 28 October 1987, 3, NSAEBB no. 238, http://nsarchive.gwu.edu/NSAEBB/NSAEBB238/russian/Final1987-1028\%20Gorbachev\%20Letter\%20to\%20Reagan.pdf.

${ }^{90}$ RRPL, Robert E. Linhard files, RAC box 19, Memorandum, E. Rowny to Carlucci: Where do we go from here on arms control?, 6 November 1987; and Memorandum, Ermarth to Linhard and Sandra Kelly: Conversation with Kampelman, 3 November 1987.
} 
time' in order to 'turn the tables on the Soviets and use the [Moscow Summit] deadline against them.' 91

When in Washington for the December 1987 summit, Shevardnadze sensed that decisions were now flowing upward, rather than being made at the top. Reagan was clearly hamstrung in arms control policy by the National Security Directives he had been persuaded to sign. The President confessed rather pathetically to a frustrated Gorbachev that both of them had 'problems with bureaucracy'. ${ }^{92}$ Such obstruction was not new, of course, but at Geneva and Reykjavik Gorbachev had galvanized Reagan, who in turn generated the energy and will to surmount numerous obstacles. In the twilight of his second term, however, weary and perhaps already exhibiting the symptoms of Alzheimer's disease, Reagan was no longer so ready to cut through the red tape. And as a lame-duck president facing a legislative branch controlled by the Democrats, and with many of his own party still vehemently anti-Soviet, Reagan had much less scope to take radical action. It was not until 27 May 1988, on the eve of the Moscow Summit, that the Senate voted to ratify the INF Treaty. The delay, reminiscent of SALT II's fate in 1979-80, handcuffed START

\footnotetext{
${ }^{91}$ RRPL, Robert E. Linhard files, RAC box 19, Handwritten notes, Linhard, NSGP and summit III, undated; Memorandum, Ermarth to Linhard: Summit dynamics; and Memorandum, Rowny to Carlucci: Where do we go..., 2 .

92 Memcon, Working luncheon with Gorbachev, 12:40 p.m.-2:10 p.m., 10, 10 December 1987, NSAEBB no. 238 http://nsarchive.gwu.edu/NSAEBB/NSAEBB238/usdocs/Doc\%2019\%20(Working\%20Lunch\%20Reagan\%2 0Gorby\%2012.10.87).pdf.
} 
negotiators ahead of the Moscow summit and also undermined the Kremlin's confidence in the Americans. The last straw was the refusal of the US Navy to sacrifice its sea-launched cruise missiles, which would block START until its resolution in $1991 .{ }^{93}$

For his part, Gorbachev was in a weaker position over START than he had been over INF. The Soviet military was jealous of nuclear 'parity' with the United States - a hard-won gain from the summitry of the early 1970s. The INF Treaty had dismantled almost five times as many Soviet missiles as American, including SRINFs against which the United States had never developed their own equivalents. So military hawks resisted additional concessions on strategic weapons, despite Gorbachev's conviction that 'without a significant reduction in military spending we will not be able to solve the problems of perestroika' ${ }^{94}$

At the Moscow summit, which ran from 29 May to 2 June 1988, American objectives were unambitious. The White House simply aimed to 'consolidate' the gains' already made, warning against 'exaggerated expectations' on the future pace of SovietAmerican rapprochement or of the reform process in the Soviet Union. ${ }^{95}$ The event was consequently longer on pageantry than on substance. Reagan rhapsodized about liberty and enterprise to students at Moscow State University and hosted Soviet political dissidents at

\footnotetext{
${ }^{93}$ Matlock, Reagan and Gorbachev, 277-9.

${ }^{94}$ Notes, Chernyaev: Politburo session, 25 February 1988, NSAEBB no. 251, doc. 2, 1, http://nsarchive.gwu.edu/NSAEBB/NSAEBB251/2.pdf.

${ }^{95}$ NSDD-305: Objectives at the Moscow summit, 26 April 1988, NSAEBB no. 251, doc. 8, 1-2, http://nsarchive.gwu.edu/NSAEBB/NSAEBB251/8.pdf.
} 
the US embassy. The two leaders signed ratification documents for the INF Treaty and took their 'impromptu' walk around Red Square. Gorbachev deemed Reagan's confession that Soviet Union was no longer the 'evil empire' to be 'one of the genuine achievements' of the summit. ${ }^{96}$

The atmosphere was constructive and affable, with little of the ideological posturing of Geneva or Reykjavik. Overall, Moscow was more significant for Gorbachev’s reform agenda than for Soviet-American relations. The Summit allowed him to outflank rivals such as Yegor Ligachev on the right and Boris Yeltsin on the left, who protested that perestroika and glasnost were proceeding either too quickly or too slowly. Ahead of Reagan's arrival, Gorbachev circulated a list of domestic policy changes and then rammed them through the XIX Communist Party Conference at the end of June. These included the first elected legislature in Russia since the October Revolution. Gorbachev did not foresee that these reforms would contribute to the eventual disintegration of the Soviet Union.

The Moscow summit was therefore the 'coronation' without a crown, the unfulfilled climax of a succession of meetings that had begun in Geneva two-and-a-half years before. Its significance was largely symbolic; yet the symbolism of that moment in Red Square was profound.

\footnotetext{
${ }^{96}$ Gorbachev, Memoirs, 457.
} 
Summitry had facilitated, indeed energized, Reagan and Gorbachev's efforts to reduce the nuclear danger and improve superpower relations through dialogue and negotiation. For brief but heady moments at the summit the two men escaped from their bureaucratic minders and dared to share their dreams. Their four meetings did not transcend the Cold War but they helped significantly to break the ice. Skilful intermediaries, notably Shultz and Shevardnadze, helped turn icebreakers into breakthroughs, most notably the INF Treaty of December 1987, which in turn served to defuse the superpower arms race. In the United States, these parleys and meetings brought flexibility and ingenuity to the policymaking process, before an internal counter-attack moderated the pace of change on arms control at the strategic level. In the Soviet Union, the summits empowered Gorbachev and fostered creative political thinking, yet his innovations would eventually, albeit unintentionally, reform the empire he had inherited out of existence. In Europe, the Reagan-Gorbachev summitry - though conducted over the heads of the Europeans - set the stage for a veritable transformation in the geopolitics of the Cold War. 